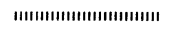

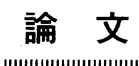

Wandoan炭液化重質オイル中の無極性成分の化学構造

(キーワード 石炭液化油, 重質炭化水素, 骨格構造, FIMS)

-1988. 7.19 受理一

化学技術研究所 杉本 義一, 三木 康朗, 丹羽 吉夫

大場 昌明, 山田谷正子

\section{1. 緒 言}

石炭液化技術開発において, 液化生成物の詳細な構 造解析は, 循環溶媒の性状把握, 製品の用途開発, さ らには液化反応機構の解明等のために, きわめて重要 な課題である。液化生成物中の比較的軽質な成分につ いては, 分析機器の性能の飛翟的な向上により，その 化学構造がかなり明らかになってきている。著者らも， これまで留出油の化学構造について検討し, ガスクロ マトグラフィーによるWandoan炭液化油中の極性成 分1) および無極性成分2) の分析, FI質量分析法

(FIMS)を用いた石炭液化油等の組成分析 ${ }^{3)}$ ５) につ いて報告している。これらの報告の中で，酸塩基抽出 や高速液体クロマトグラフィー－(HPLC) による分離, さらには脱水素化やシリル化等の前処理と, GC/MS あるいはFIMSによる分析を組み合わせることによっ て, 留出油留分の詳細な分析が可能であることを示し た。

一方，蒸留残渣などの重質成分の多くは，多環芳香 環を基本骨格構造として有していると考兄られるが， その化学構造については未だ不明な点が多い。重質成 分は多くの石炭液化プロセスに打いて循環溶媒として 使用されており，その水素供与性が大きいことや二次 水素化触媒の活性低下に及ぼす影響が大きいことが知 られている。したがって，その化学構造に対する知見 は，これらの実用的な見地から必要であるとともに， さらには石炭液化機構の解明や石炭構造の推定等にお いてもきわめて重要である。

これまで, 重質成分の分析は ${ }^{1} \mathrm{H}-\mathrm{NMR},{ }^{13} \mathrm{C}-\mathrm{NMR}$ と元素分析による平均構造解析が主であった6) 7\%。最 近, Boduszynskiら ${ }^{8)}$ 9) はHPLC分離とFIMS分析を 組み合わせることによって，SRCパイロットプラン 茨城県つくば市東 $1-1$
トで得られた液化油中の高沸点炭化水素の組成分析を 行っている。

著者らは，これまでトルェン溶媒やテトラリン溶媒 中での石炭液化反応に拈ける生成物の分析を行ってき た。本研究では，テトラリン溶媒中での Wandoan炭 の液化反応を行い, 得られた蒸留残渣中の無極性成分 の化学構造について, HPLC分離とFIMS分析によっ て検討した。石炭液化油中の重質な無極性成分の含有 率はそれ程高くないが，その骨格構造はへプタンに可 溶な重質極性成分やアスファルテン等の骨格構造と類 似しているものと予想されることから, 石炭液化油中 の重質成分の構造を検討するためには大变重要である と考えられる。

\section{2. 実 験}

\section{1 石炭および試薬}

実験に用いた石炭はWandoan炭（豪州亜瀝青炭） で，その分析值は灰分 $8.0 \%$, 炭素 $76.2 \%$, 水素 $5.7 \%$, 窒素1.0\%, 硫黄 $0.2 \%$, 酸素 (diff.) $16.9 \%$ であっ た。触媒は市販のへマタイトを $\mathrm{H}_{2} \mathrm{~S}-\mathrm{H}_{2}$ 気流下, $450^{\circ} \mathrm{C}$ で予備硫化して用いた。液化反応および溶剂分別等に は特級試薬を, HPLCには液体クロマトグラフィー用 試薬をそのまま使用した。

\subsection{Wandoan炭の液化反応}

反応は, 内容積 $500 \mathrm{ml}$ の回転擤拌式オートクレーブ にWandoan炭100g, テトラリン $100 \mathrm{~g}, \alpha-\mathrm{Fe}_{2} \mathrm{O}_{3}$ (硫化) $1 \mathrm{~g}$ 充填し, 反応温度 $450^{\circ} \mathrm{C}$, 水素初圧 $9.8 \mathrm{MPa}$, 反 応時間 1 時間で行った。生成物の分離手順および重質 生成物の収率をFig. 1亿示す。まずオートクレーブ内 の固体および液状生成物をTHFで洗い出し, 不溶分を ろ別した。THF可溶分をェバポレーターで濃縮し, 10倍量のトルェンを加え, 生じた沈殿をろ別し,さらら にトルェンにて一昼夜yックスレー抽出してプレアス 


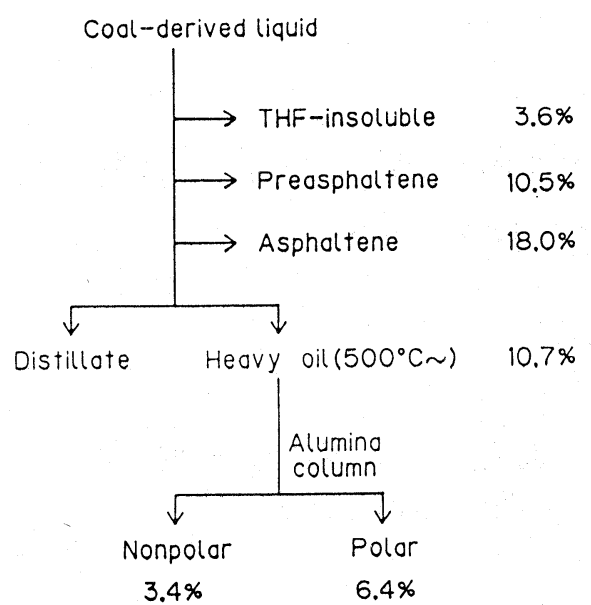

Fig. 1 Separation scheme of the coal-derived liquid

ファルテンとトルェン可溶分に分離した。ついでトル エン可溶分をェバポレーターで濃縮し，10倍量のへプ タンを加え, 生じた沈殿をろ別し, さらにへプタンに て一昼夜ソックスレ一抽出してアスファルテンとへプ タン可溶分を分離した。ヘプタン可溶分は, 減圧蒸留 により留出油と蒸留残渣 (重質オイル ; 常圧換算 $500^{\circ} \mathrm{C}$ 〜)に分離した。

各成分の収率はTHF不溶分 $3.6 \%$ ，プレアスファル テン $10.5 \%$, アスファルテン $18.0 \%$, 重質オイル 10.7 \%であった。

\section{3 重質オイルの分離方法}

$80 \mathrm{~g}$ の活性アルミナ(和光純薬製)を充填した内径 $2 \mathrm{~cm}$, 長さ $50 \mathrm{~cm}$ のカラムの上部に約 $2.5 \mathrm{~g}$ の重質オイ ルを添加し, ベンゼン $400 \mathrm{ml}$ 扰よびベンゼンノメタ ノール ( 1 : 1 ) $200 \mathrm{ml}$ で順次溶出し, それぞれ無極性 成分および極性成分とした。分離操作は 3 回行ったが， 無極性成分の回収率は $30.7,31.6,32.3 \%$ であり，極 性成分の回収率は58.8，60.1，60.1\%であった。した がって今回, 分析の対象とした重質無極性成分の収率 は原料炭に対して3.4wt\%(daf)である。

つぎに $\mu$-Bondapak $\mathrm{NH}_{2}$ カラム(Waters社製, $19 \times 150 \mathrm{~mm}$ )を備えたHPLCを用いて，重質無極性成 分を五フラクションに分離した。Fig. 2に無極性成分 の液体クロマトグラムと各フラクションの収率を示す。

\section{4 分析方法}

重質無極㤬成分中の各フラクションの質量分析には, 日本電子製JMS-HX100型質量分析計を用いた。試料 はガラス管に充填したアルミナ粉末に浸み込ませ,ク

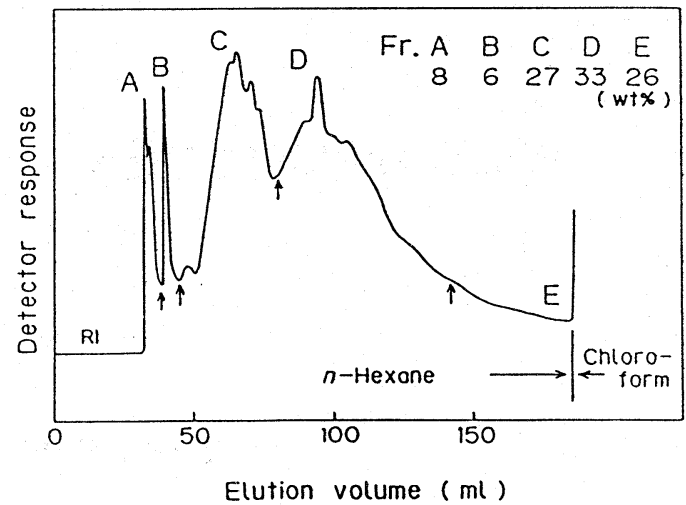

Fig. 2 HPLC separation of the nonpolar fraction in Wandoan coal-derived heavy oil

オーツウールで栓をした後, 直後導入プローブにより 導入した。試料導入と同時に測定を開始し, 試料を室 温から $400{ }^{\circ} \mathrm{C} て ゙ 16^{\circ} \mathrm{C} / \mathrm{min} の$ 速度で加熱して，イオン が観測されなくなるまで磁場掃引を繰り返した。全ス キャンのスペクトルをFACOM M-380システムへ転 送し，同位体元素の影響を補正した分子イオンスペク トルを得た。さらに分子イオンスペクトル中の各分子 イオンを14質量ごとにまとめ, $\mathrm{C}_{\mathrm{n}} \mathrm{H}_{2 \mathrm{n}+\mathrm{z}}$ で定義される Z数により分類した。同一Z数で分類されるグループ は，共通の骨格構造をもつアルキル同族体と考えられ る。分子イオンスペクトル法のデータ処理については, 前報3)の方法に基ついて行った。

$\mathrm{GC}$ 分析は，キャピラリーカラム $(0.2 \mathrm{~mm} \times 25 \mathrm{~m})$ を 備えたHewlett-Packard社製の5890A GCを用いて, $80^{\circ} \mathrm{C}(10 \mathrm{~min})$ から $260^{\circ} \mathrm{C}$ ま $5{ }^{\circ} \mathrm{C} / \mathrm{min} て ゙$ 昇温させて行 った。

\section{3. 結果および考察}

\subsection{HPLCによる重質無極性成分の分離}

Fig. 2に示したように, Fr. A〜Fr. Eの収率はそれ ぞれ $8 ， 6 ， 27 ， 33 ， 26 \mathrm{wt} \%$ であった。つぎに, 分析 用カラム(ガスクロ工業製 Nucleosil- $5 \mathrm{NH}_{2}, 4.6$ $\times 250 \mathrm{~mm}$ )を用いて，Fr. A Fr. Dおよび標準化合物 を分析した結果をFig. 3に示す。Fr.Aには，エイコ サンと同じ保持容量である大きなピークのあとに，紫 外吸収をもつ小さなピークが存在する。 $\mathrm{NH}_{2}$ 系カラム では一般に二重結合の数，すなわち縮合環の大きさに よって分離されるが, アルキル側鎖が長くなるほど早 く溶出することが知られている8)10)。本結果でもベン ゼンに比ベてヘプタデシルベンゼンはかなり早く溶出 している。また，多環の飽和化合物は直鎖パラフィ 


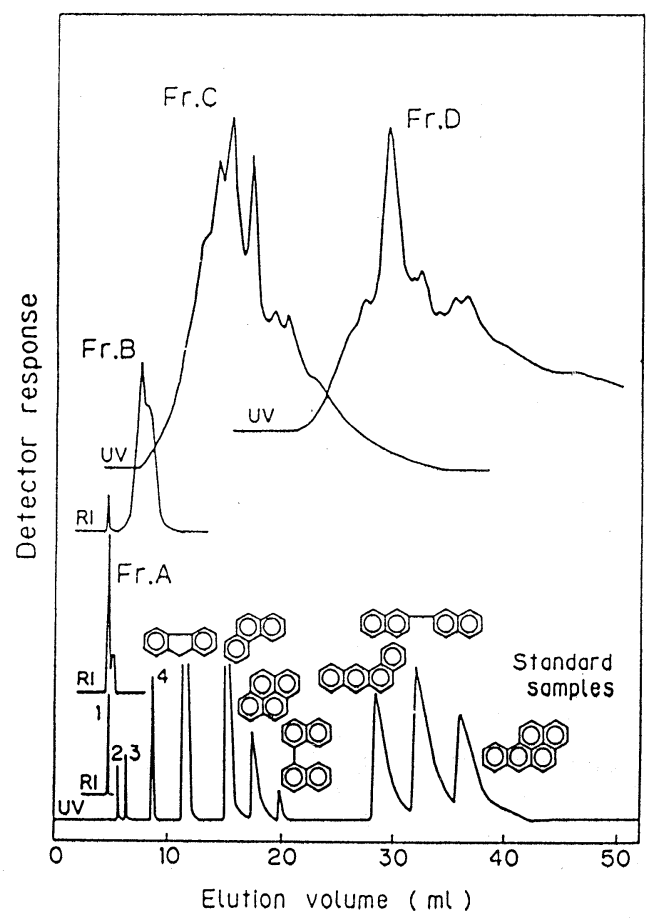

Fig. 3 Elution profiles of Fr. A Fr. D in the nonpolar fraction and standard compounds ; 1 : eicosane, $2:$ heptadecylbenzene, 3 : benzene, $4:$ naphthalene
ン類よりも遅く溶出することが知られている8)。これ らのことから，Fr. Aに存在する後者のピークは一個 の芳香環と長いアルキル側鎖をもつ芳香族化合物や飽 和多環化合物であると予想される。

Fr. Bの主成分はベンゼンとナフタレンの間に溶出 しており，二個の芳香環をもつ多環化合物であると推 定される。Fr. Bにはほかに直鎖パラフィン類に相当 するピークが見られ，Fr. A との分離が完全ではなか ったものと思われる。

Fr.Cには，フェナントレンおよびピレンと同程度 のところに溶出する成分が非常に多く，フルオレンよ り前に，あるいはベンゾアントラセン付近に溶出する 成分は少ない。したがってFr.Cの主成分は三個およ び四個の芳香環をもつ多環化合物であり，後者の場合 その芳香環はピレン型に縮合していると予想される。

Fr. Dは，標準化合物の保持容量との比較から， へ ンゾアントラセン型縮合四環芳香族構造あるいはベン ゾピレン型縮合五環芳香族構造をもつ多環化合物が主 成分であると考えられる。また，Fr. Eには保持容量 $60 \mathrm{ml}$ までに溶出する成分は認められず，六環縮合環 以上の芳香族化合物が主成分であると考えられる。

標準化合物のらち，ビナフチルの保持容量は異性体 により著しく異なり，1，1'一体はその二重結合の数か ら予想されるところより著しく早く溶出している。す
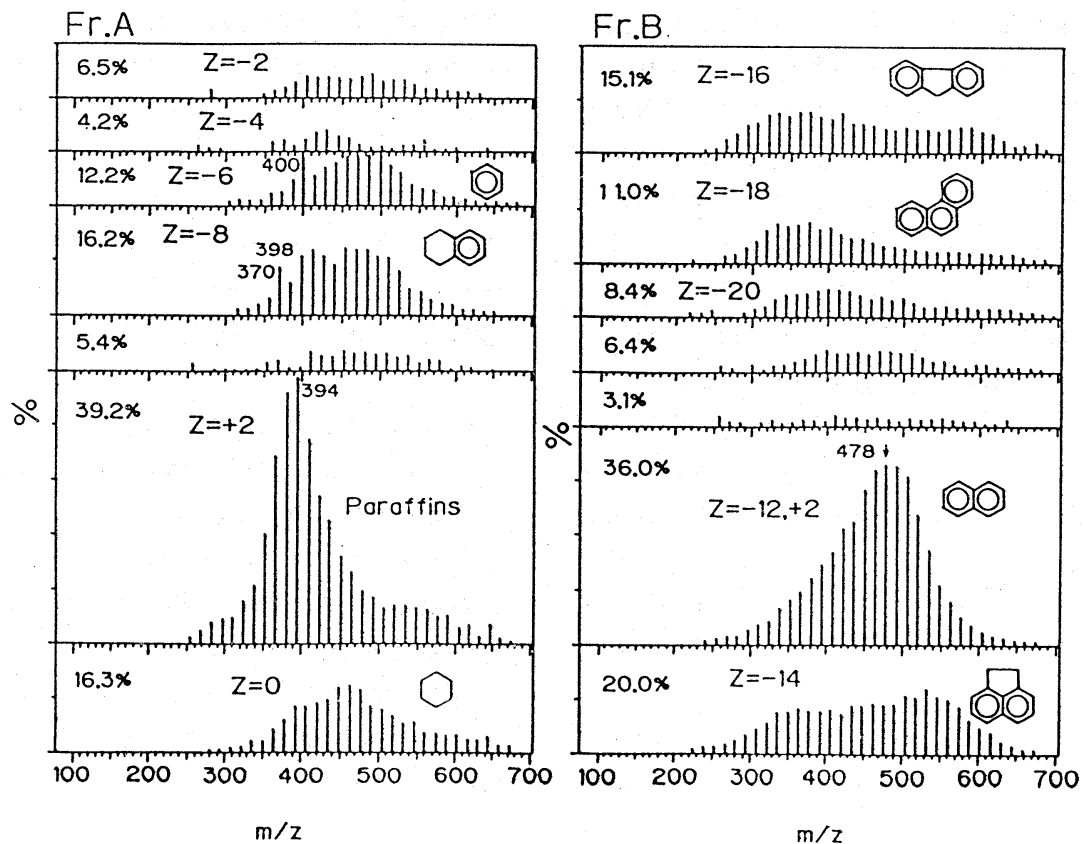

Fig. 4 Molecular ion spectra of Fr. A and Fr. B 


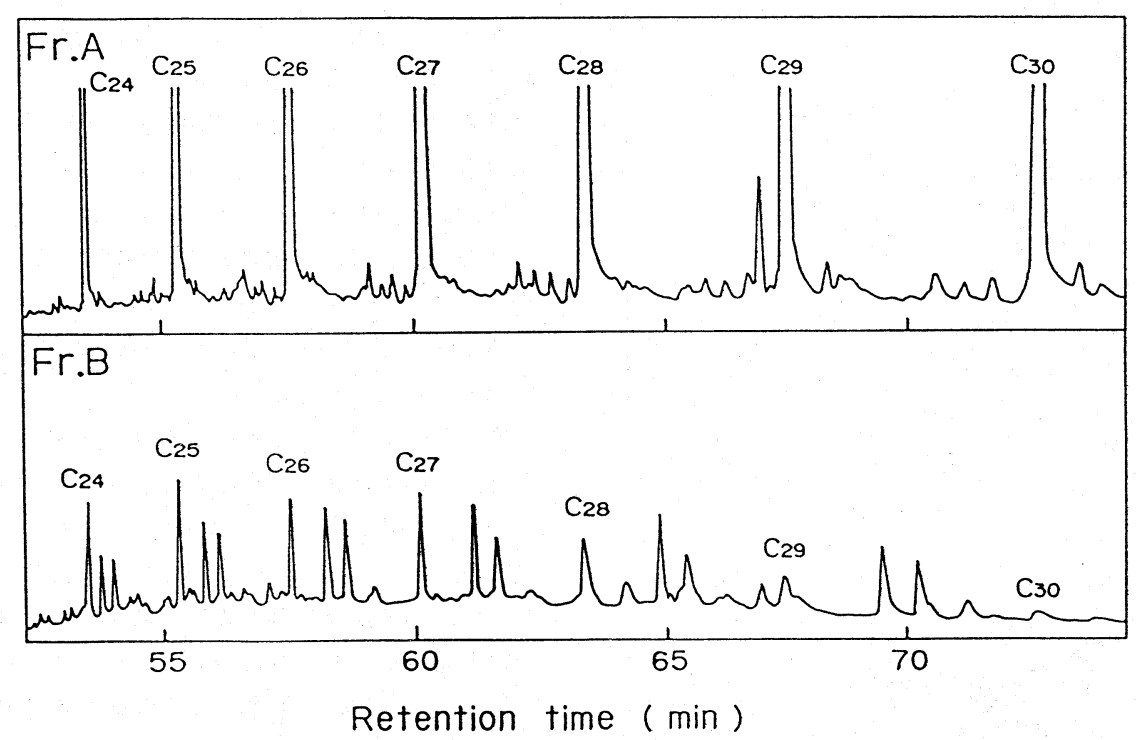

Fig. 5 Gas chromatograms of Fr. A and Fr. B ; $\mathrm{Cn}$ is $n$-paraffin with carbon number $\mathrm{n}$

なわち，1１'-ビナフチルはFr. Cに，また2,2'ービナ フチルはFr.Dに含まれることになる。

\subsection{Fr. AおよびFr. Bの化学構造}

Fig. 4にFr. AおよびFr. Bの分子イオンスペクトル および各 Z数系列に対する骨格構造の一例を示し，

Fig. 5にはFr. AおよびFr. Bのガスクロマトグラムの 一部を示す。Fr. Aの分子イオンスペクトルには，パ ラフィン類 $(Z=+2)$ が $39 \%$ と非常に多く含まれてい るが，その主成分はガスクロマトグラフによる分析か ら，直鎖パラフィン類であることが示された。反応温 度 $450^{\circ} \mathrm{C}$ での石炭の液化反応に扎いては，炭素数 25 程 度の直鎖ペラフィン類が最も多く生成する11)が，本試 料では蒸留の影響により, 炭素数28の直鎖パラフィン (m/z 394)が最も多くなっている。そのほかの成分と しては, $Z=0$ 系列が $16 \%, Z=-6$ 系列が $12 \%, Z$ $=-8$ 系列が16\%含まれている。 $Z=0$ およ゙ $Z=-6$ 系列は，それぞれアルキルシクロへキサン類，アルキ ルベンゼン類であると考兄られるが，いずれも炭素数 33付近に極大を持っている。したがって, これらのア ルキル側鎖炭素数の極大は27付近であり, 石炭液化反 応で生成する直鎖パラフィン類の炭素数分布との相関 がみられる。

$\mathrm{Z}=-6$ 系列における $\mathrm{m} / \mathrm{z} 400$ および $\mathrm{Z}=-8$ 系列に おける $\mathrm{m} / \mathrm{z} 370,398$ の特異なピークは，Boduszynski ら9)が報告している飽和化合物中にもみられ，それぞ れ四環および五環の飽和多環化合物と考えられている。
$\mathrm{Z}=-8$ 系列には二つの分布がみとめられるが, $\mathrm{m} / \mathrm{z}$ 480 付近の分布は，後述するアルキルナフタレン類の 四水素化物，すなわちアルキルテトラリン類であると 予想される。

Fr. Bでは， $Z=-12 ，+2$ の化合物タイプが $36 \%$ と 主成分である。Fig. 5に示したFr. Bのガスクロマトグ ラムには, Fr. Aの混入による $\mathrm{C}_{24} \sim \mathrm{C}_{30}$ の直鎖パラフ ィンのピークのほかに, 二組の規則的なピークが存在 する。これらのピークはGC/MS分析により，長鎖の アルキル基をもったナフタレン類 $(Z=-12)$ ，すな わち 1-および2-アルキルナフタレンであることが示 された。分子イオンスペクトルでは，炭素数25のアル キル基が付いたナフタレン $(\mathrm{m} / \mathrm{z} 478)$ が最も多い。著 者らは, テトラリンを溶媒とした石炭の液化反応の際 に,メチルナフタレン, メチルテトラリンが非常に多 く生成し，これらは溶媒のメチル化物であること年， また, $450^{\circ} \mathrm{C}$ におけるWandoan炭の液化反応で生成す る直鎖ペラフィン類は炭素数 25 程度のものが最も多い こと11)を示した。これらの結果から, 石炭液化反応中 に長鎖のアルキル基の溶媒への付加が起こっているこ とが示唆される。Fr. Bには，ほかに $Z=-14,-16$, -18系列が多く含まれているが，いずれる多くのア ルキル側鎖炭素をもっている。 $Z=-18$ 系列は, HPLC分離の際に, アルキル側鎖の影響により早く溶 出したフェナントレン/アントラセン類であると考え られる。 

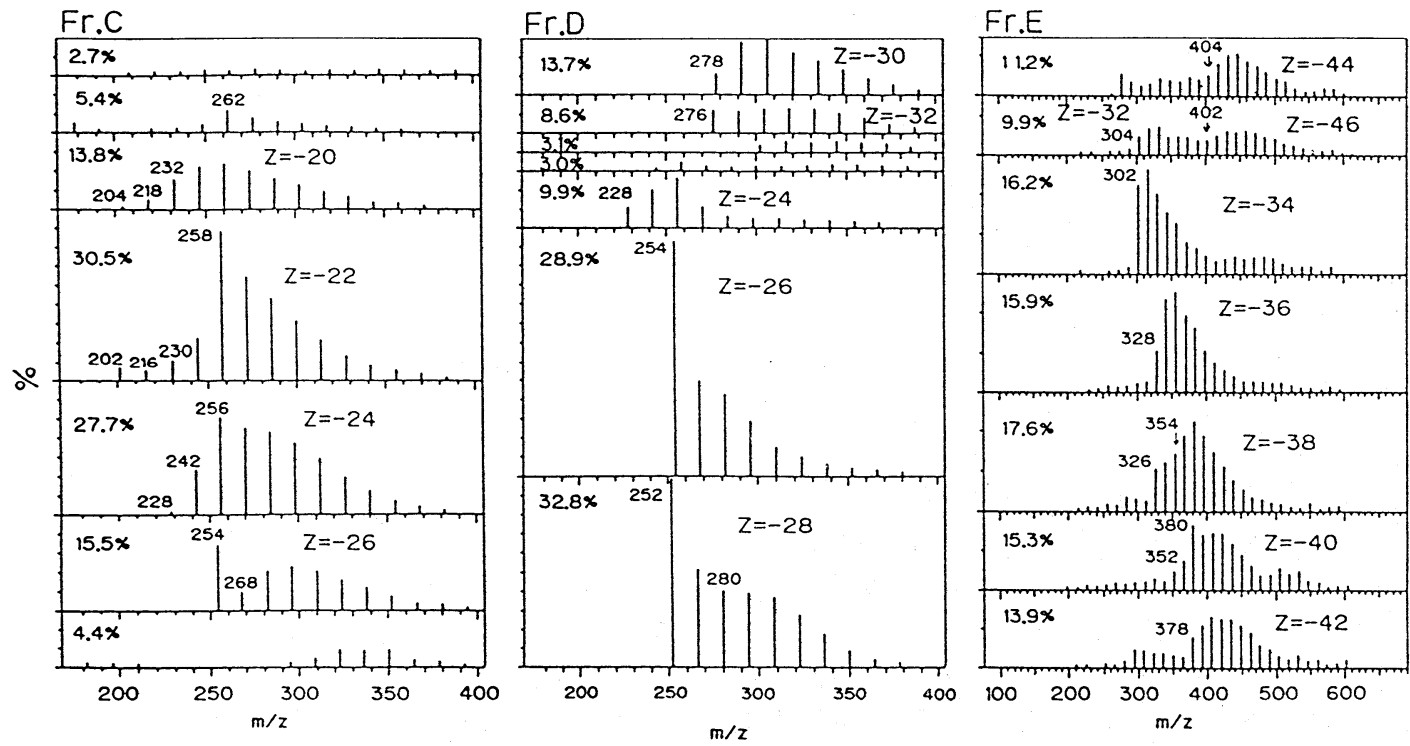

Fig. 6 Molecular ion spectra of Fr. C, Fr. D and Fr. E

\subsection{Fr. C, Fr. DおよびFr. Eの化学構造}

Fig. 6に，Fr.C，Fr.D执よびFr. Eの分子イオンス ペクトルを示す。Fr. A〜Fr. Dの分子イオンスペクト ルには奇数ピークはほとんど含まれていないが, Fr. Eの分子イオンスペクトル中には約 $15 \%$ の奇数ピーク が含まれていた。活性アルミナカラムを用いて無極性 成分を分離した際に，窒素化合物の一部が溶出したも のと考えられる。ここでは偶数ピークについてのみ検 討した。

\section{3 .1 特徵的なピークの由来}

石炭液化油中の各 $Z$ 数系列は, 一般になめらかな分 布をもち，アルキル側鎖を持たない縮合多環芳香族化 合物よりもアルキル側鎖を持った同族体の方が多く存 在している。Fig.6に示すよ5に, Fr. C, Fr.Dには $\mathrm{m} / \mathrm{z} 252,254,256,258,262$ の特異なピークが，ぬた Fr. Eにはm $/ 2$ 380の特異なピークが存在している。前 述したようにテトラリンを溶媒とした石炭液化反応で は, 溶媒の二量化やメチル化等の反応が起こることが 指摘されている2)が，ガスクロマトグラフ分析によれ ば，Fr.Cには1,1'一および1,2’ービナフチルが，また Fr. Dには2, 2'-ビナフチル, ペリレンが多く含まれて いた。したがって， m/z 254，258，262の特異なピー クはそれぞれビナフチル，テトラヒドロビナフチル， オクタヒドロビナフチルによるすのと考えられる。ま た, $\mathrm{m} / \mathrm{z} 252,256$ の特異なピークは石炭の分解生成 物と考えるよりも，ビナフチルがさらに脱水素縮合
した化合物(ペリレン，ベンゾフルオランテン等)およ びその四水素化物であり，さらに，Fr. Eに存在する $\mathrm{m} / \mathrm{z} 380$ の特異なピークはナフタレンの三量体である と考える方が妥当である。

Fr. CおよびFr. Dのビナフチル (m/z 254)の生成量

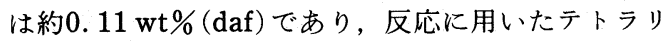
ン量に比べれば著しく少ない。これに対して, ペリレ ン/ベンゾフルオランテン $(\mathrm{m} / \mathrm{z} 252)$ とビナフチル (m/z 254)の生成量の比はかなり大きく，テトラリン あるいはナフタレンが二量化してビナフチル類になる のはむずかしいが，ビナフチル類がさらに縮合してぺ リレンバンゾフルオランテン類になるのはかなり容 易であると考えられる。このように，石炭液化反応に おいては溶媒どらしの反応や溶媒とアルキルラジカル との反応といった縮合反応も並行して起こっているが, このことは液化油中の縮合多環構造の一部は, 液化反 応中に生成することを示唆している。

\section{3 .2 石炭液化油中の芳香族成分の縮合骨格構造}

分子イオンスペクトル法により分類される各 $Z$ 数系 列は, 共通の骨格構造をもつアルキル同族体であり,そ の系列の最小質量数のピークは骨格構造に由来してい る。したがって, 各 Z 数系列の最小質量数から骨格構 造についての知見が得られる。しかしながら，水素化 が進んだ試料においては，同一Z数系列に多くの骨格 構造タイプが存在し, 最小質量数の確認, 骨格構造の 推定が困難である。今回の分析試料では，ビナフチル 
(m/z 254) およびペリレン/ベンゾフルオランテン $(\mathrm{m} / \mathrm{z} 252)$ はその四水素化物 $(\mathrm{m} / \mathrm{z} 258$ および $\mathrm{m} / \mathrm{z} 256)$ よりも $3 \sim 4$ 倍多く存在すること, また, 同一実験で 得られた無極性留出成分 $\left(280^{\circ} \mathrm{C} \sim 400^{\circ} \mathrm{C}\right)$ の脱水素化処 理前後の分子イオンスペクトルには大きな違いがな (12)ことから, 部分水素化物は少ないものと考えられ る。Fig. 6 に打いて, 各 Z 数系列の最小質量数として, 228, 278, 328, 378(228+50n), 202, 252, 302, 352, 402(202+50n), 204, 254, 304, 354, 404(254 $+50 \mathrm{n}), 276,326(276+50 \mathrm{n})(\mathrm{n}=0,1,2,3,4)$ が認められる。

石炭液化油中の芳香族成分の主要な骨格構造は, 心 ンゼン環，五員および六員のナフテン環，ビフェニル タイプの結合，さらにはフラン環などから構成される。 本試料では部分水素化物は少ないものと考兄られるこ とから，六員のナフテン環は考慮しない。石炭液化油 のガスクロマトグラフによる分析214)では, 骨格構造 としてベンゼン $(\mathrm{m} / \mathrm{z} 78)$, ナフタレン $(\mathrm{m} / \mathrm{z} 128)$, フ ェナントレン, アントラセン $(\mathrm{m} / \mathrm{z} 178)$, クリセン, $\mathrm{a}$ ーベンジアントラセン $(\mathrm{m} / \mathrm{z} 228)$, インダン $(\mathrm{m} / \mathrm{z}$ 118), アセナフテン, ビフェニル $(\mathrm{m} / \mathrm{z} 154)$, ジベン ゾフラン, ジフェニルメタン $(\mathrm{m} / \mathrm{z} 168), フ_{ェ}$ ニルナ フタレン $(\mathrm{m} / \mathrm{z} 204)$, フルオレン $(\mathrm{m} / \mathrm{z} 166)$, ベンゾ フルオレン $(\mathrm{m} / \mathrm{z} 216)$, ピレン, フルオランテン $(\mathrm{m} / \mathrm{z} 202)$ などが検出されている。これらの GC 分析 の結果と今回の結果を考光合わせると, 液化油中の芳 香族成分の主要な縮合骨格構造の質量数は, Table 1 のように三グループ( Group-1, Group-2, Group-3) に整理することができる。
Group-1はベンゼン，ナフタレン，フェナントレン /アントラセン‥川の゙ループで，その質量数は $78+50 \mathrm{n}(\mathrm{n}=0,1 ， 2 ， 3 \cdots)$ で表される。ピレン/フル オランテンに五員環がついた骨格構造タイプ $(242+50 \mathrm{n})$ の存在も考光られる。質量数50の增加は 縮合環が 1 個增兄ることに相当している。Group-2は インダンにベンゼン環が縮合したタイプ $(118+50 n)$, アセナフテン/゙フェニルにベンゼン環が縮合したタ イプ $(154+50 \mathrm{n})$ 扩よびジベンゾ[def, mno]クリセン にベンゼン環が縮合したタイプ $(276+50 \mathrm{n})$ である。 また，ジベンゾフランにベンゼン環が縮合したタイプ $(168+50 \mathrm{n})$ もこのグループに含まれる。Group-3は フルオレンにベンゼン環が縮合したタイプ $(166+50 \mathrm{n})$ 拉よびピレン/フルオランテンにベンゼン 環が縮合したタイプ $(202+50 \mathrm{n})$ である。同一 Z 数系 列には数個の骨格構造タイプが存在するが，分子イオ ンスペクトル法では, これらの骨格構造タイプを区別 することはできない。

\subsubsection{Fr. C, Fr. D扐よびFr. Eの骨格構造}

Fr. C, Fr. DおよびFr. Eの各Z 数系列に対して推定 される骨格構造をまとめてFig. 7に示す。Group-1に 分類される $Z=-24,-30,-36,-42$ 系列は, 図 中に示すよらにベンゼン環が $4 \sim 7$ 個縮合した構造で あると考えられる。ベンゼン環の縮合する位置の違い によって数多くの異性体が存在するが，ここではその 一例を示した。先に述べたようにアミノプロピル系カ ラムによるHPLC分離では, 二重結合の数, すなわち 芳香環の大きさによって分離され，Fr.Cには $\mathrm{a}$-ベン ゾアントラセン，クリセンなどの縮合四環芳香族化合

Table 1 Mass number of major aromatic skeltal structures in coal-derived liquids

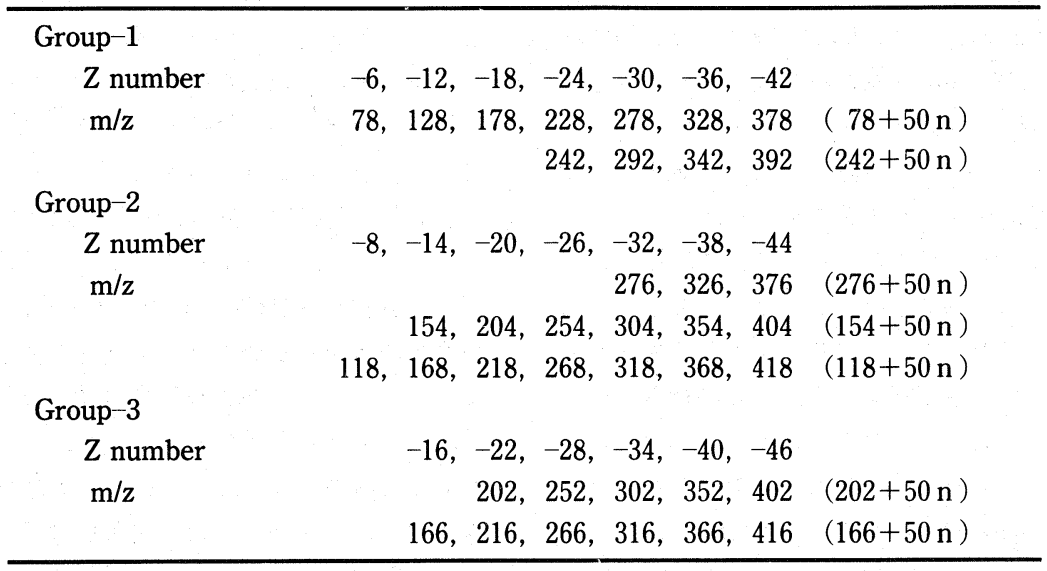




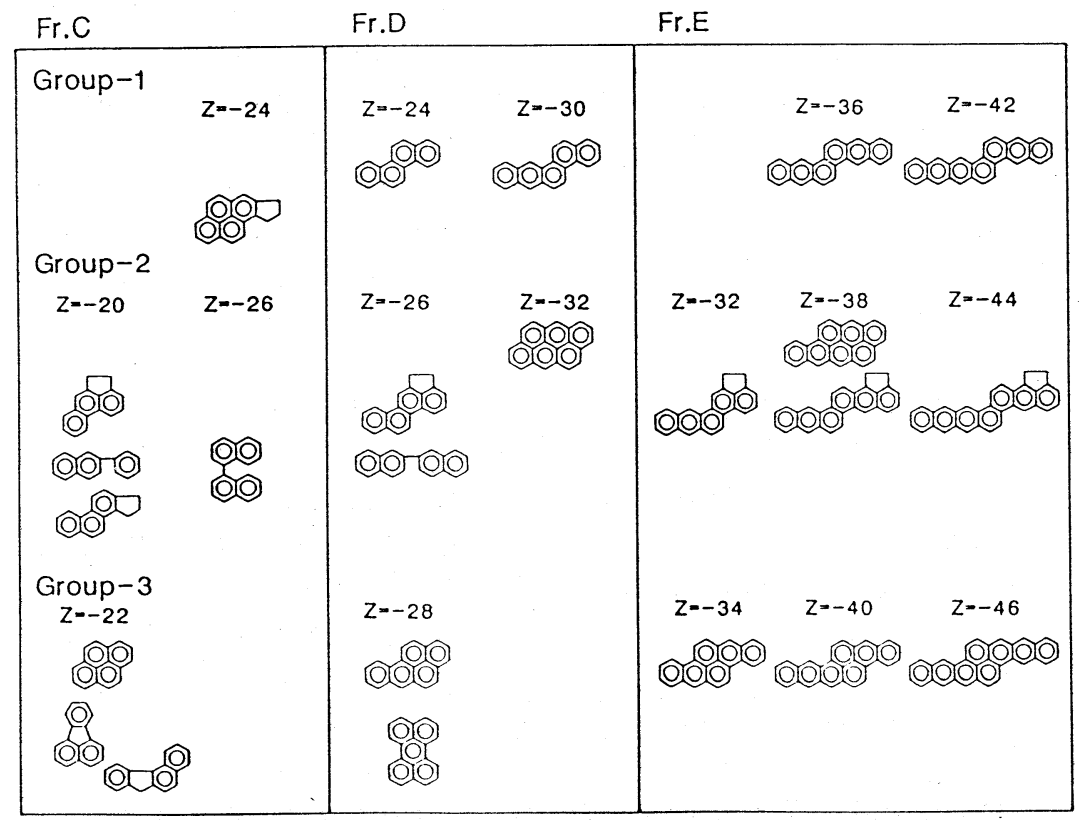

Fig. 7 Representative skeltal structures of Fr. C, Fr. D and Fr. E

物は含まれない。したがって，Fr. Cの Z =-24系列 の $\mathrm{m} / \mathrm{z} 228,242$ の構造として, 図中に示すようなピ レン/フルオランテンに五員環がついた構造が考えら れる。しかしながら，縮合多環芳香族化合物にアルキ ル側鎖がついた場合のHPLCでの溶出挙動は明らかで なく，側鎖炭素数の増加によって早く溶出し，芳香環 の大きさから予想されるよりも前のフラクションに含 まれることが十分考えられる。すなわち，Fig. 6に示 されるよらに, Fr. Dの $Z=-24$ 系列の分布はアルキ ル側鎖炭素数が少ない方に偏っており，アルキル側鎖 炭素数の多い縮合四環芳香族化合物はFr.CのZ $=-24$ 系列に含まれている可能性が高い。また，Fr. Dの $Z=-26,-28$ 系列についても同様に, アルキル 側鎖炭素数の多い化合物はFr. Cの $Z=-26,-28$ 系 列に含まれているものと考えられる。

Group-2に分類される $Z=-20,-26,-32$, $-38,-44$ 系列はインダン, アセナフテン, ビフェ ニル, ジベンゾフラン構造を基本とし，これらにベン ゼン環が縮合した骨格構造をもっている。さらに $Z=$ -32以下の系列には, ジベンゾ[def, mno]クリセン 構造, ベンゾ[ghi]ペリレン構造にベンゼン環が縮合 したタイプも存在する。

Group-3に分類される $Z=-22,-28,-34$, $-40,-46$ 系列はフルオレン, ピレン, フルオラン
テン，ペリレン構造にベンゼン環が縮合した骨格構造 である。

これまでも石炭液化油中の重質成分はおもに多環芳 香族化合物からなると考只らていた。本研究の結果 から，重質無極性成分の主要な骨格縮合環構造は $228+50 \mathrm{n}, 202+50 \mathrm{n}, 204+50 \mathrm{n}, 276+50 \mathrm{n}$ $(\mathrm{n}=0,1,2,3,4)$ の質量数で表されることが示唆 された。この規則性は石炭液化油中の芳香族成分の縮 合骨格構造に共通したものであった。しかし，同一 Z 数系列に存在する骨格構造タイプの含有割合, アミノ プロピル系カラムを用いたHPLC分離でのアルキル側 鎖の影響などについては，今後さらに詳細な検討が必 要とされる。

\section{4. 結 言}

石炭液化重質残椬中の無極性成分をHPLCにより五 フラクションに分離し，FIMSを用いて骨格縮合環構 造の検討を行った。

重質無極性成分は，Fig. 7 に示すよらな四環以上の 多環芳香族化合物が主成分であり，その骨格構造の質 量数は, $228+50 \mathrm{n}, 202+50 \mathrm{n}, 204+50 \mathrm{n}, 276+50 \mathrm{n}$ $(\mathrm{n}=0,1,2,3,4)$ で表された。ほかには，直鎖パラフ イン類, アルキルシクロヘキサン類, 多くのアルキル 側鎖炭素をもった単環，二環，三環芳香族化合物が少 量含まれていた。 
本試料中には, 溶媒の二量化や溶媒とアルキルラジ カルとの縮合反応による生成物が多く検出されており， 液化油中の縮合多環構造の一部は，石炭液化反応過程 において生成するものと推察された。

\section{文献}

1）杉本義一，三木康朗，山田谷正子, 大場昌明，日 化, 1984, 755

2）杉本義一，三木康朗，山田谷正子，大場昌明，日 化, 1984, 1959

3）丹羽吉夫，石川啓一郎，森田弥左衛門，杉本義 一，燃協誌，64，175(1985)

4）杉本義一，三木康朗，丹羽吉夫，大場昌明，山田 谷正子，日化，1988，166

5）杉本義一，三木康朗，丹羽吉夫，大場昌明，山田 谷正子，日化，1988，181
6) Kanda, N., Itoh, H., Yokoyama, S. and Ouchi, K., Fuel, 57, 676(1978)

7) Ouchi, K., Katoh, T. and Itoh, H., Fuel, 60, 689 (1981)

8) Boduszynski, M. M., Hurtubise, R. J., Allen, T. W. and Silver, H. F., Anal. Chem., 1983, 55, 225

9) Boduszynski, M. M., Hurtubise, R. J., Allen, T. W. and Silver, H. F., Anal. Chem., 1983, 55, 232

10）横山 晋, 続木直英, 内野洋之, 加藤 隆, 真田 雄三, 日化, 1983，405

11）杉本義一, 三木康朗, 山田谷正子, 大場昌明, 燃 協誌, 64, $100(1985)$

12）杉本義一, 三木康朗, 山田谷正子, 大場昌明, 日 化第56春季年会予稿集，940(1988)

13）三木康朗，杉本義一，燃協誌，63，28(1984)

\title{
Chemical Structures of Nonpolar Fraction in Wandoan Coal-derived Heavy Oil
}

\author{
Yoshikazu Sugimoto, Yasuo MIKI, Yoshio NiWA, \\ Masaaki OBA and Shoko YAMADAYA
}

(National Chemical Laboratory for Industry)

SYNOPSIS : - The chemical structures of the nonpolar fraction in Wandoan-coal derived heavy oil were investigated by Field-ionization mass spectrometry (FIMS).

The nonpolar fraction of the heavy oil were separated into five compound -type classes by high-performance liquid chromatography (HPLC). The FIMS analyses of those compound-type subfractions indicated that the skeltal structures were polycondensed aromatic rings which had molecular weights represented by $228+50 \mathrm{n}, 202+50 \mathrm{n}, 204+50 \mathrm{n}, 276+50 \mathrm{n}(\mathrm{n}=0,1,2,3,4)$. A small amount of $n$-paraffins was also contained.

Naphthalenes with long alkyl chains, binaphtyls and their hydrogenated compounds were also detected in significant amounts, and they were supposed to be formed by recombination of solvent with alkyl radical and dimerization of solvent, respectively. The occurence of these recombination reaction implyed that a part of polycondensed aromatic rings might be formed during coal liquefaction.

\section{Key Words}

Coal-derived liquid, Nondistillable hydrocarbons, Skeltal structures, FIMS 